\title{
Essay/Commentary
}

\section{ON SUFFERING, FINDING MEANING, DIVINE LOVE AND ETERNAL LIFE}

\author{
Jove Jim S. Aguas \\ University of Santo Tomas, Philippines
}

The COVID-19 global pandemic, the Extra-Judicial killings (EJK) here in the Philippines, and the natural calamities we experienced have put human suffering in our collective consciousness. Perhaps one of the most enigmatic human experiences is suffering. We often associate suffering with misery, pain, loneliness, and even evil, but the mystery of suffering goes beyond its cause or reason because it touches on the very meaning of suffering, especially when we consider the suffering of the innocent.

St. John Paul II (1984) in Salvifici Doloris (\#3, henceforth SD) writes: "In whatever form, suffering seems to be, and is, almost inseparable from man's earthly existence." Indeed, suffering is part of our human existence, and there is no escaping it in this temporal life. Suffering is as much of a part of human existence as death. The moment we are born, we are bound to suffer and then die. We experience pain, illness, disability, hunger, poverty, grief, hatred, frustration, heartbreak, guilt, humiliation, anxiety, loneliness, self-pity, and death. We witness the mass execution of innocent people, the unimaginable toll of natural calamities on communities, and the poverty and hunger of the poor, to name a few examples of mass suffering.

Human suffering reminds us of the Buddhist first noble truth, which states that there is suffering, human existence is suffering. According to the Buddha, suffering comes in many forms. Three obvious kinds of suffering correspond to the first three sights the Buddha saw on his first journey outside his palace: old age, sickness, and death. However, according to the Buddha, the problem of suffering goes much deeper. Life is far from ideal and comfortable; it frequently fails to live up to our expectations. Human beings are subject to desires and cravings, and more often, we desire the things of this world. However, even when we are able to satisfy these desires, the satisfaction is only temporary. Pleasure does not last, or if it does, it becomes monotonous. Even when we do not suffer from external causes like illness or bereavement, we are unfulfilled and unsatisfied. This is the truth of suffering; it is connected to our desires, according to the Buddha.

It is only in death that we are able to free ourselves from suffering. Death offers us escape. Death, however, while something that is inevitable to happen, is not an option, escape is not an option. We continue living despite the suffering and miseries. However, given that we cannot escape suffering in this life, does it mean that our life 
with all its pains and miseries is a wasted and meaningless existence? How do we make sense of this suffering, especially of those seemingly senseless suffering of people most of which were inflicted by his fellow human beings - like the violence committed against the lowly and poor, the injustices against the perceived enemies of the state, or the senseless killing of the innocents or the miseries of a family who lost a loved one during this pandemic, or the suffering of the victims of conflicts and wars?

When we encounter or experience this senseless suffering, we ask, what is the meaning of all this? Moreover, the more we ask, we seem to be resigned to the silence that confronts us, a silence that seems to tell us there is no answer to our question. The choice is between resignation or willing ourselves to find meaning out of such a desperate and miserable situation.

Viktor Frankl (1992), in Mans' Search for Meaning, describes that suffering is a potential springboard for having a need for meaning and finding it. Frankl, who was himself a victim of the Holocaust and survived four different concentration camps in Nazi Germany, writes: "When a man finds that it is his destiny to suffer, he will have to accept his suffering as his task; his single and unique task. He will have to acknowledge the fact that even in suffering, he is unique and alone in the universe. No one can relieve him of his suffering or suffer in his place. His unique opportunity lies in the way in which he bears his burden" (Frankl 1992, 86). Indeed, we can find meaning in life even in hopeless situations, situations that we cannot change but give us the opportunity to change ourselves. Frankl (1992, 116-117), sounding optimistic, writes: "We must never forget that we may also find meaning in life even when confronted with a hopeless situation when facing a fate that cannot be changed. For what then matters is to bear witness to the uniquely human potential at its best, which is to transform a personal tragedy into a triumph, to turn one's predicament into a human achievement. When we are no longer able to change a situation-just think of an incurable disease such as inoperable cancer - we are challenged to change ourselves."

In his Man's Search for Ultimate Meaning, Frankl (2000) further expressed optimism in life. He $(2000,141)$ writes, “... there must be a meaning to life under any conditions, even the worst conceivable ones. But how shall we explain this finding which so much contradicts the ubiquitous feeling of meaninglessness?" According to Frankl, if we investigate how the man in the street goes about finding meaning, it turns out that three avenues lead up to meaning fulfillment. First, doing a deed or creating a work; second, experiencing something or encountering someone; in other words, meaning can be found not only in work but also in love." However, the most important is the third avenue; "when facing a fate we cannot change, we are all called upon to make the best of it by rising above ourselves and growing beyond ourselves, in a word changing ourselves." This is true even for the 'tragic triad' of pain, guilt, and death. In these circumstances, we turn suffering into a human achievement and accomplishment; we derived from guilt the opportunity to change for the better, and we see in life's transitoriness an incentive to take responsible action (Frankl 2000, 141-142).

However, in the face of seemingly meaningless suffering, finding meaning is almost impossible. Imagine, for example, losing loved ones in a brutal anti-drug campaign or losing everything because of the successive calamities. Frankl (2000, 142) shared the story, based on the account of a German bishop, of a woman years 
after World War II who wore a bracelet of baby teeth mounted in gold. She was asked about it by a doctor, and she told him that those teeth belonged to her sons and daughters, who were taken to the gas chambers and died during the Holocaust. Shocked, the doctor asked her how she could live with such a bracelet. She quietly replied that she is now in charge of an orphanage in Israel. Meaning may be found even in such unbearable suffering, which is why life remains potentially meaningful despite everything. Of course, it does not mean that we need to suffer in order to find meaning. This is only to say that meaning can still be found in the face of unavoidable and seemingly meaningless suffering.

When we think of our suffering here, we cannot but focus on the meaning that is beyond this temporal existence - the ultimate meaning. This is what Frankl (2000, 143) referred to as the meaning of the whole, the meaning of one's life as a whole along-range meaning. Every part of life, every experience, every encounter offers to some extent some meaning or carries with it a particular meaning. However, when we look at our entire life, we can only comprehend its whole meaning at its end. The final meaning of life reveals itself at the very end. So, when we start thinking about the overall meaning of life, the less comprehensible such meaning to us. Frankle (2000, 143) said that the more comprehensive the meaning, the less comprehensible it is. Thus, the ultimate meaning of one's life is necessarily beyond comprehension. Regardless of whether we comprehend the overall meaning of our own lives, there is always that "will to ultimate meaning." Moreover, this will to ultimate meaning is connected to religious beliefs. Frankl $(2000,153)$ stressed that religion reveals itself as the fulfillment of the will to ultimate meaning.

For us Christian, our will for ultimate meaning is anchored on our faith, in our faith in God, and in His promise of eternal life. The unavoidability and seeming meaninglessness of our suffering here in this temporal life can only be given meaning when we relate our suffering to our faith in God and his promise of happiness in His Kingdom for eternity. Suffering then becomes an opportunity for eternal happiness. Such seeming meaninglessness is, after all, the source of our salvation and happiness. However, how do we understand this somewhat mysterious meaning of suffering?

St. John Paul II, who was himself a victim of atrocities in his native Poland and had to suffer the successive loss of his loved ones, first his mother, then his older brother, and finally his father, and found himself without a family for all his adult life, and had to suffer from Parkinson disease for the remaining years of his life tackles in Salvifici Doloris the intimate relationship between suffering, Divine Love, and eternal salvation.

According to St. John Paul II (1984, SD), the field of human suffering is wide, complex, and multi-dimensional; man suffers in different ways. When we look closer at suffering, we can see that it is more deeply rooted in humanity itself. It is man who suffers, and it is also man who wonders about the meaning of suffering. Human suffering can be distinguished between physical suffering and moral suffering, based on the human being's two dimensions, namely the bodily and spiritual elements. The body is the immediate or direct subject of physical suffering; the spirit is the direct and immediate object of moral or spiritual suffering. Physical suffering is present when "the body is hurting" in some way, whereas moral suffering is "pain of the soul" (SD, 5). 
Suffering can also be distinguished between personal suffering and suffering in the social or interhuman sense. This world of suffering exists as it were "in dispersion," meaning we suffer individually. However, according to St. John Paul II, "every individual, through personal suffering, constitutes not only a small part of that world, but at the same time, that world is present in him as a finite and unrepeatable entity. The world of suffering possesses, as it were, its own solidarity. People who suffer become similar to one another through the analogy of their situation" (SD, 8). Therefore, although the world of suffering exists "in dispersion," or individually, it is shared by the community of persons and presents a singular challenge to the communion and solidarity of people.

When we consider the world of suffering in its personal and collective or communal meaning, we recognize that the world, during the moments of an extreme case of suffering like famines, wars, pandemic upheavals, natural calamities, comes together to focus and concentrate on these mass sufferings. "Human suffering then evokes compassion; it also evokes respect." For in suffering is contained the greatness of a specific mystery - the deepest need of the heart and the deep imperative of faith (SD, 6). Man suffers whenever he experiences any evil. In the Old Testament, suffering and evil are identified with each other. In suffering, there is always an experience of evil, which causes the individual to suffer. Thus, the reality of suffering prompts the question about the essence of evil. (SD 7).

In Christianity, we recognize the essential goodness of existence, the goodness of the Creator, and the goodness of creation. Everything that exists in so far as it is created by God is good. However, within God's creation, there exists evil. Hence, other people believe that God must be the cause or source of evil. Christian philosophers like St. Augustine and St. Thomas Aquinas consider evil as the lack or privation of goodness or perfection. According to St. Augustine, in principle, since every substance is a participation in the sovereign Good, which God, it is not necessarily evil. Evil as such, as the contrary of good, cannot be a substance but is a limit or a privation of being, of substance, or of good. Its source cannot be God, for it lies entirely in the deficiency of creatures. St. Augustine in the Enchiridion (1955, Chap. 4, \#12) writes, "All of nature, therefore, is good, since the Creator of all nature is supremely good ... For good to be diminished is evil." St. Augustine (1955, Chap. 4, \#12) continues, "when, however, a thing is corrupted, its corruption is an evil because it is, by just so much, a privation of the good. Where there is no privation of the good, there is no evil. Where there is evil, there is a corresponding diminution of the good." St. Thomas agrees with St. Augustine that evil, both physical and moral is a privation of goodness, of perfection in being and in action. In the Summa Theologica (1947, Part I, q. 48, a. 1), he writes: "Evil is neither a being nor a good. One opposite is known through the other, as darkness is known through light. Hence also what evil is must be known from the nature of good." If suffering is a form of evil, then suffering exists on account of evil, which means that suffering as evil is a certain lack, limitation, or distortion of good. We could say that man suffers because of a good in which he does not share or is deprived of a certain good. He particularly suffers when he ought to have a share in this good but does not have it. Sickness as suffering is a privation of health; loneliness as suffering is a privation of happiness, war as suffering is a privation of peace, etc. 
Since suffering and evil are always associated with God's existence, this makes the meaning of suffering and the problem of evil all the more perplexing and complicated. While the beauty of God's creation opens the human soul to the existence of God, to his wisdom, power, and greatness, evil and suffering seem to obscure the image of an omnipotent and omnibenevolent God. When we face the enormity of suffering and death caused by war or natural disasters or the mass murder of innocents, or the atrocities of repressive regimes against its people, it is difficult to think of a benevolent God. How could such a benevolent God allow such horrific things to happen to his people? No rational consideration of sin and punishment for sin can comprehend the suffering of the victims of the Holocaust and wars, the victims of famines and other forms of violence and human miseries, for example, and no concept of a God who controls human life and destiny can comprehend it, except to conclude that God is not a benevolent God.

However, the question that always comes to mind is, why do we suffer? It is a question not just of the cause or reason of suffering, but more importantly, a question of its purpose, of its meaning. What is the meaning of suffering? Only the suffering human being knows that he is suffering, and he wonders why. It is he who suffers, and he suffers all the more when he does not find a satisfactory answer.

The story of Job is a very vivid expression of human suffering. The story of this just man, who without any fault of his own is tried by innumerable and unimaginable sufferings - he lost his properties, he lost his family and was afflicted with leprosy. He was abandoned by his friends, who said that he must have done something seriously wrong to be punished by God. The accusation against Job expresses the view that suffering always strikes a man as punishment for a crime or wrongdoing or sin. The friends of Job convince him of the moral justice of the evil and attempt to justify to themselves the moral meaning of suffering. In their eyes, suffering can have a meaning only as a punishment for sin, therefore only on the level of God's justice, who repays good with good and evil with evil (SD, 9).

The Old Testament writings show us that suffering is a punishment inflicted by God for human sins or moral evil. Corresponding to the moral evil of sin is punishment, which guarantees the moral order laid down by the will of the Creator and Supreme Lawgiver. The objective moral order demands punishment for transgression, sin, and crime. Thus, suffering appears as a "justified evil" (SD, 10).

Job, however, rejects the belief that identifies suffering with punishment for sin. He knows that he has not offended God and that he does not deserve the punishment. God himself reproves the friends of Job for their accusations and recognizes that Job is not guilty. Hence, Job's suffering is the suffering of someone who is innocent. However, why would God allow an innocent man to suffer? Is the suffering inflicted on him a form of punishment? According to St. John Paul II, such is a mystery, that the individual is unable to penetrate completely by his own intelligence. (SD, 11)

While it is true that suffering has a meaning as punishment, when it is connected with a fault, it is not true that all suffering is a consequence of a fault and has the nature of a punishment (SD, 12). This presents the problem of the suffering of an innocent man: suffering without guilt. Job was not punished because he did no wrong, nor did 
he offend God. There was no reason for inflicting a punishment on him, even if he has been subjected to a grievous trial. God permitted this testing as a result of Satan's provocation. For Satan had challenged before the Lord the righteousness of Job. Job's story poses a difficult question - "why" of suffering; it shows that suffering strikes the innocent. Thus, the question remains, why permit the innocent to suffer?

According to St. John Paul II, the sufferings inflicted by God upon the Chosen People or to the innocent include an invitation of his mercy, which corrects to lead to conversion. Thus, these punishments were designed not to destroy but to discipline people and effect conversion. Punishment as a form of suffering serves to repay the objective evil of the transgression with another evil. However, the suffering of the innocents creates the possibility of rebuilding goodness in the subject who suffers. Such is the personal meaning of suffering; it is a means for getting closer to God. The martyrs endured unbearable sufferings, and this made them closer to God.

St. John Paul II expresses that suffering must serve for conversion, that is, to rebuild goodness in the subject, who can recognize the divine mercy in this call to repentance. The purpose of penance is to overcome evil, which under different forms lies dormant in man. Its purpose is to strengthen the goodness both in man himself and in his relationships with others, especially with God (SD, 12).

For St. John Paul II, however, to understand the true meaning of suffering, we need to look at suffering in the context of divine love, which is the ultimate source of the meaning of everything that exists. Love is the richest source of the meaning of suffering, which always remains a mystery. Thus, Christ invites us to enter into the mystery in order to discover the "why" of suffering, as far as we are capable of grasping the sublimity of divine love. (13)

Love as the fullest source of the answer to the meaning of suffering is manifested in the Crucified Christ - Christ hanging on the Cross. In the Crucified Christ, we find the ultimate meaning of suffering. "For God so loved the world that he gave his only Son, that whoever believes in him should not perish but have eternal life." These words introduce us to the very heart of God's salvific work. The suffering of Christ in the Cross reveals the very essence of God's salvific work rooted in his divine love. God saved us from evil by suffering on the Cross. Our salvation or liberation from evil is attained through the suffering of Christ. Hence salvation is closely bound up with the problem of suffering (SD, 14). What made this possible is God's divine love. Hence, God's salvific work is closely tied up with His Salvific love.

Our liberation or salvation from evil is achieved through the suffering of the Son of God. This is the fundamental and definitive meaning of suffering. God loved man so much that He gave his only-begotten Son so that man "should not perish" "but have eternal life." He suffered for us to be saved, and in our own personal sufferings, we share in the suffering of Christ. The suffering of the innocents is a participation in the suffering of Christ.

Therefore God wills that man to be saved from eternal damnation where man loses his "eternal life." The loss of eternal life is the definitive suffering, and the loss of eternal life is a rejection of God. However, instead of rejecting us, God gave his only-begotten Son to man primarily to protect man against this definitive evil and definitive suffering - the rejection of God. In his salvific mission, Christ strikes evil right at its 
transcendental roots, from which it develops in human history in sin and death (SD, 14), which are the very basis of the loss of eternal life. By suffering and dying on the Cross, he conquered sin and death and, by his resurrection, attained eternal life for us.

In order to understand the meaning of suffering and relate it to the meaning of life, one must be open to the transcendent and the divine. Without this openness to the transcendent and the divine, suffering loses its ultimate meaning. Life has meaning despite all the seemingly senseless sufferings when we relate it to what Frankl calls the will to ultimate meaning. However, this will to ultimate meaning finds its fulfillment in the redemptive act of God, in the salvific love of God, which was manifested in the Crucified Christ.

\section{REFERENCES}

Frankl, Viktor. 1992. Man's search for meaning: An introduction to logotherapy. Fourth Edition. Translated by Ilse Lasch. Boston, Massachusetts: Beacon Press. Frankl. Viktor. 2000. Man's search for ultimate meaning. New York: Basic Books.

John Paul II. 1984. Salvifici Doloris. Libreria Editrice Vaticana https://www.vatican.va/content/john-paulii/en/apost_letters/1984/documents/hf_jp-ii_apl_11021984_salvificidoloris.html. Accessed: February 24, 2021.

St. Augustine. 1955. Enchiridion: On Faith, Hope, and Love. Translated and edited by Albert Outlers. https://www.tertullian.org/fathers/augustine_enchiridion_02_trans.htm\#C4. Accessed: May 1, 2020.

St. Thomas Aquinas. 1947. Summa theologica. Benziger Bros. Edition. Translated by Fathers of the English Dominican Province. http://dhspriory.org/thomas/summa/. Accessed: June 1, 2015. 